\title{
4D Reservoir Geomechanical Modelling Provides Safe Drilling Operations in North Kuwait Stacked Reservoirs
}

\begin{abstract}
The mature Raudhatain and Sabriya fields have been in production for the last six decades. Each field consists of four main reservoirs that are vertically stacked over a depth of $12.000 \mathrm{ft}$ and separated by shales. The field development strategy is, to drill several horizontal wells within the individual reservoirs to maximize production. Some of these horizontal and highly deviated wells, experienced severe drilling problems, such as stuck pipe and side-tracking. As reservoir pressure changes during the life of the field, the stress state is modified. Such changes have an impact on well completions and the behaviour of faults. Therefore, the combined effect of well trajectory and in-situ stress changes on wellbore stability, should be thoroughly investigated. Not only is it important to understand the natural geomechanical behaviour of the reservoir during production, but it is also important to know, how to harness that behaviour to enhance productivity. At the same time, it is essential that the geomechanics of the field are understood to avoid costly mistakes. Therefore, a 4D geomechanical model that integrates geology, petrophysics, laboratory testing, fluid flow and geomechanics to obtain a representative equilibrated stress state prior to and during production was constructed. The results can be used to compute $3 \mathrm{D}$ critical drilling mud weights that provide guidelines for the placement of new wells and necessary drilling mud weights along planned wells.
\end{abstract}

Keywords: Reservoir Geomechanics, Mud weight, wellbore stability

\section{Geomechaniczne modelowanie złożowe typy 4-D umożliwia bezpieczne wiercenia w wielohoryzontowych złożach w północnym Kuwejcie}

\begin{abstract}
Złoża Raudhatain i Sabriya są eksploatowane od sześciu dekad. Każde z nich składa się z czterech głównych horyzontów odizolowanych warstwami łupkowymi w zakresie głębokości 12000 stóp. Strategia rozwiercania tych złóż maksymalizująca wydobycie obejmuje kilkanaście odwiertów poziomych i silnie krzywionych w obrębie poszczególnych horyzontów. Wiercenia niektórych z tych odwiertów napotykają trudności w postaci zakleszczenia przewodów wiertniczych i niekontrolowanych odchyleń. Na skutek zmian ciśnienia złożowego występują istotne zmiany w rozkładzie naprężeń skały złożowej. Zmiany te w istotny sposób wpływają na proces uzbrajania odwiertów oraz właściwości uskoków. W konsekwencji badania wymaga oddziaływanie trajektorii otworu i zmienionych naprężeń i jego wpływ na stabilność otworu. Dlatego istotnym staje się zrozumienie naturalnych procesów geomechanicznych zachodzących w złożu podczas procesu wydobycia jak również sposobów ich wykorzystania dla zwiększenia produktywności złoża. Jednocześnie pozwala ono uniknąć kosztownych błędów w procesie wiercenia i eksploatacji. W tym celu skonstruowano modele geomechaniczne typu 4D złóż obejmujące dane geologiczne, petrofizyczne, laboratoryjne oraz dotyczące przepływów i geomechaniki, które pozwoliły określić równowagowy rozkład naprężeń zarówno przed jak i w trakcie eksploatacji. Wyniki te mogą być wykorzystane dla określenia optymalnych parametrów wierceń takich jak lokalizacje i trajektorie otworów czy wymagane gęstości płuczki.
\end{abstract}

Słowa kluczowe: geochemika złożowa, gęstość płuczki, stabilność odwiertu.

\section{Introduction}

A variety of experiences have been encountered while drilling horizontal and high angle wells in the Lower Burgan reservoir in the Sabriya and Raudhatain fields located in northern Kuwait. Some wells have been successfully drilled, 
whereas others have faced severe drilling problems, such as stuck pipe and side-tracking. Although time-dependent shale instability is suspected as one of the main contributors to these drilling problems, the profiles of existing wells indicate that a combined effect of in-situ stress state and well trajectory on wellbore stability should also be thoroughly investigated. The field development strategy is to drill several horizontal within the individual reservoirs to maximize production. In-situ stresses vary laterally and vertically with pressure changes due to depletion, so the wellbore stability during drilling needs to be addressed at the actual pressure depletion step, to optimize well trajectories and to define a safe mud weight window at field and wellbore scales. In addition, horizontal wells may intersect fault zones where mud losses can occur and fault reactivation, induced by injection and production processes, may be a potential risk that can cause the loss of the well. Furthermore, before the wells reach the planned target depth (TD), shale layers are intersected during drilling and exposed to long openhole duration, during which time mechanical and time-dependent wellbore stability issues have been observed in the past. A wellbore stability prediction and mud weight programme recommendation for future wells will therefore be critical for successful drilling and completions.

\section{Fields Structure and Stratigraphy}

The Raudhatain and Sabriya fields lie within the Arabian basin. These are the two major anticlines, holding hydrocarbons in clastics and carbonates. The Raudhatain field structure exhibits a quasi-radial pattern [3]. Main orientations of faults are NW-SE in the Northern part of the field and SW-NE in the South-Western part. Conversely, the Sabriya field is an elongated, faulted anticlinal structure with flank dips ranging from $8^{\circ}$ to the east, to approximately $4^{\circ}$ to the west. Three main fault sets are distinguished: NNW-SSE, approximately $\mathrm{N}-\mathrm{S}$ and NWW-SEE. The main reservoirs are:
- The Mauddud carbonate reservoir consists of limestone. It is subdivided into 10 zones. The upper unit holds most of the producible hydrocarbons.

- The Burgan formation is quartz sandstone of littoral to possibly deltaic aspect, interbedded with siltstones and dark shales. It is divided into three members: Upper Burgan (sand), Middle Burgan (shale) and Lower Burgan (sand).

- The Lower Cretaceous Zubair formation consists of sand and sandstone intercalated with siltstones, shales and few thin limestone beds.

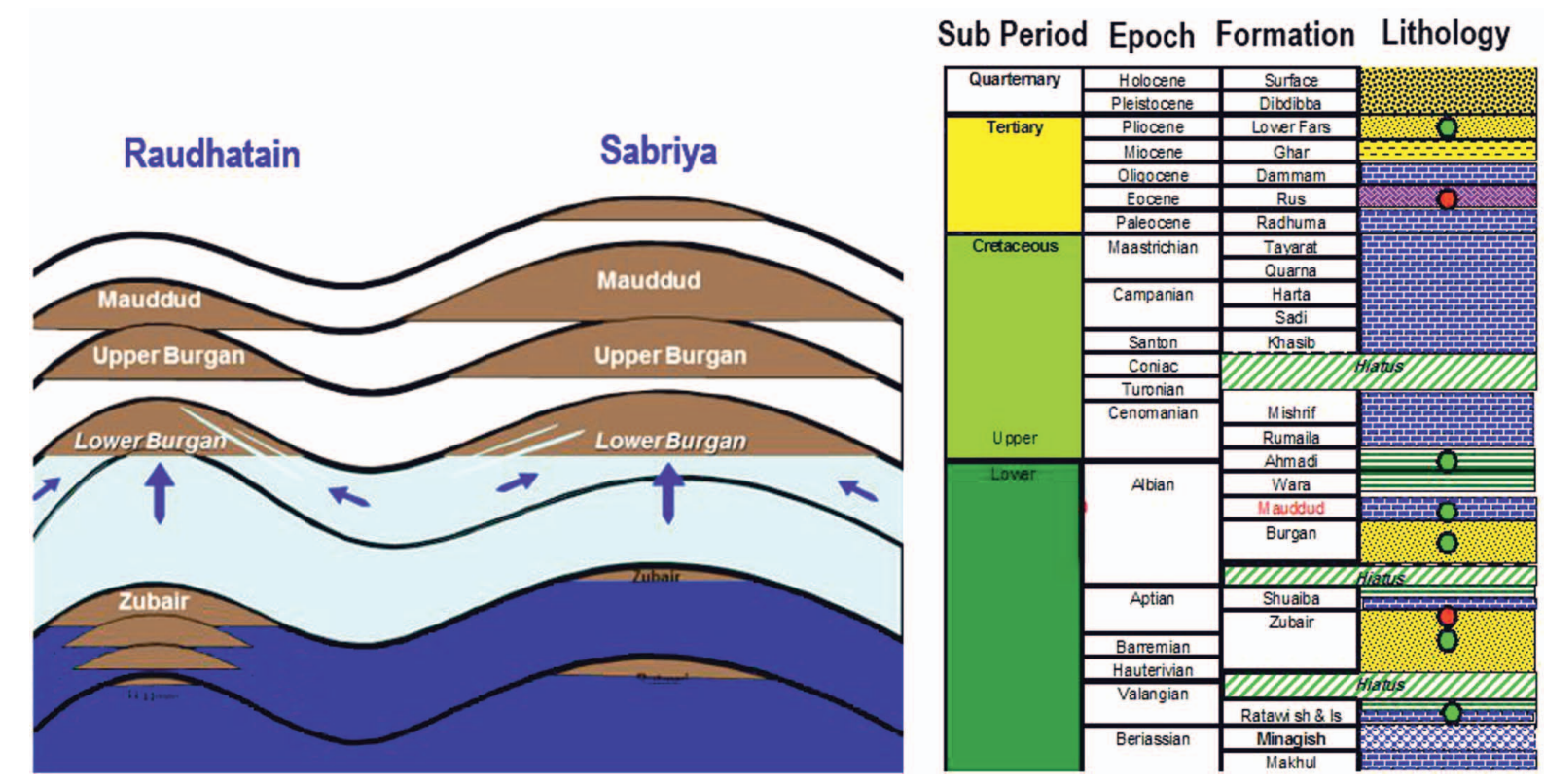

Fig. 1. Reservoirs in Raudhatain and Sabriya fields (left) and stratigraphic column (right)

\section{Drilling Complications}

Drilling wells after significant depletions in various reservoirs has been a challenge. Drilling vertical wells was relatively successful, but not completely free from instability. Dissimilarly, drilling deviated and horizontal wells experienced wellbore instability. There exist consistent wellbore instability in clastic sections, especially in deeper holes where the wellbores experienced stuck pipe, tight zones and, sometimes, cavings, similar to the issues when drilling over-pressured shales. 
Figure 2 is an example of drilling events in one of the Raudhatain wells. The drilling complications in the Raudhatain field can be summarized as:

- mud losses prominent in Dammam, Rus, Tayarat and Sadi shallow formations,

- tight hole incidents mainly across Mauddud and Burgan reservoirs,

- stuck pipe incidents in Ahmadi, Wara, Burgan and Ratawi.

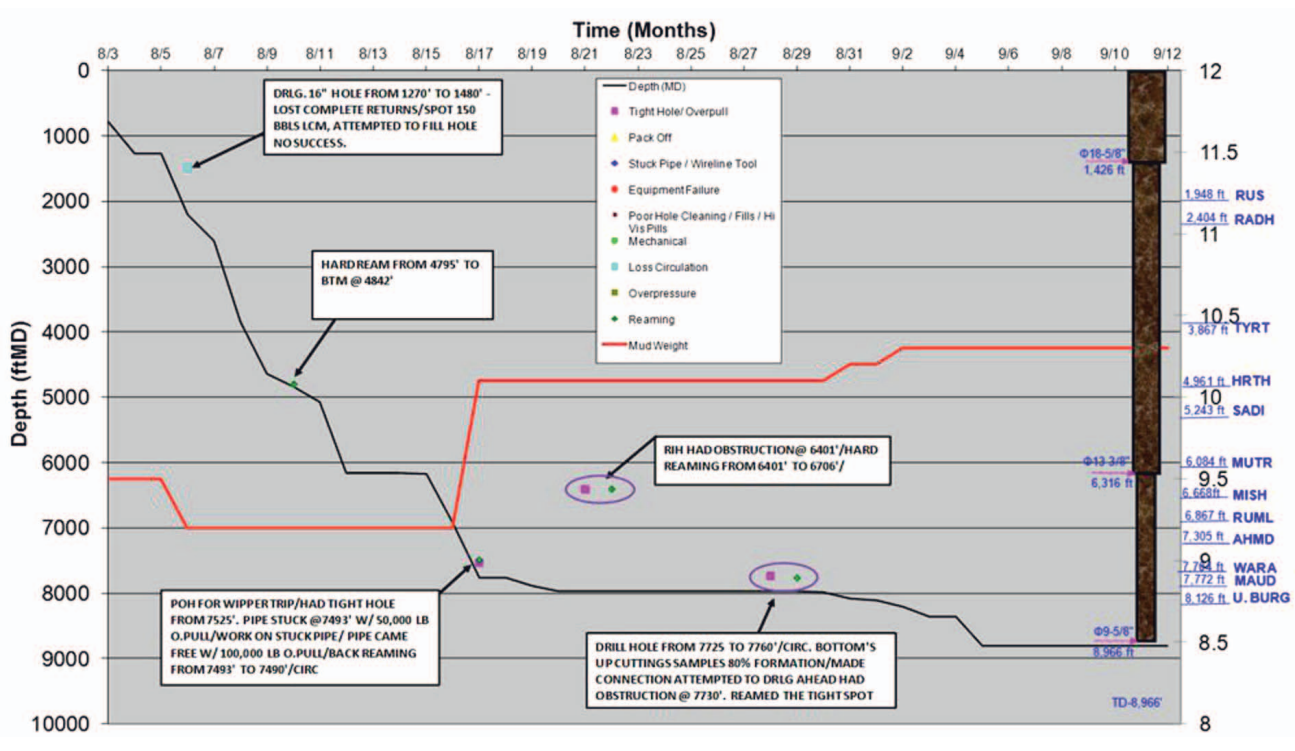

Fig. 2. Drilling events in the Raudhatain well "A"

\section{D Geomechanical Model Construction}

\section{A 3D geomechanical} model was built based on the individual reservoir models and seismic horizons. The individual reservoir models include the geometry and reservoir properties such as porosity, permeability and pore pressure. The interpreted faults from seismic data were incorporated into the geomechanical model.

Figure 3 shows the interpreted seismic horizons and fault planes for the Raudhatain and Sabriya fields. Rock elastic and strength properties were defined using porosity correlations based on an extensive database, which included well data, in-situ measurements, and triaxial test data. Figure 4 shows the 3D geomechanical model.

Fig. 4. Geomechanical model with one-quarter cut out
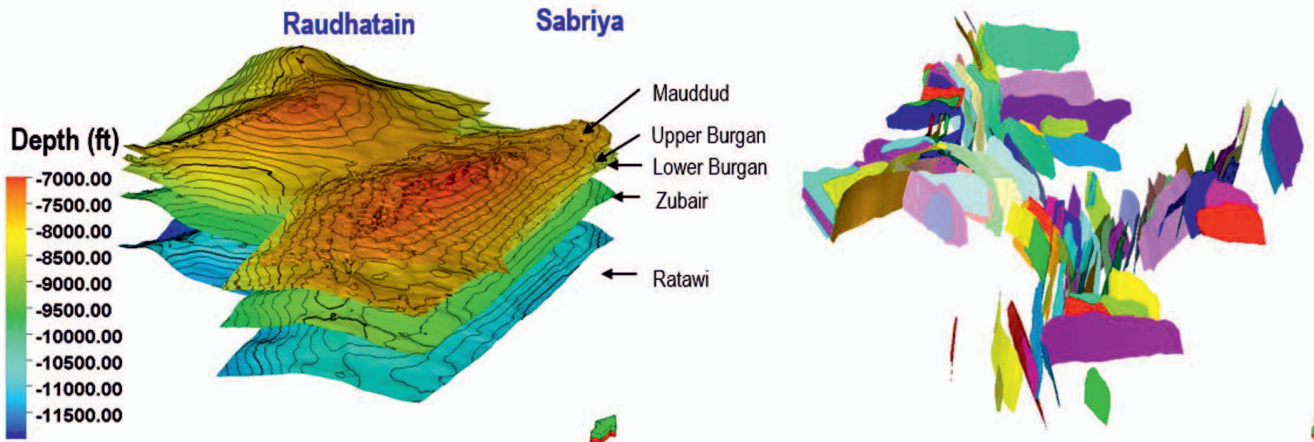

Fig. 3. Interpreted seismic horizons (left) and seismic faults (right)

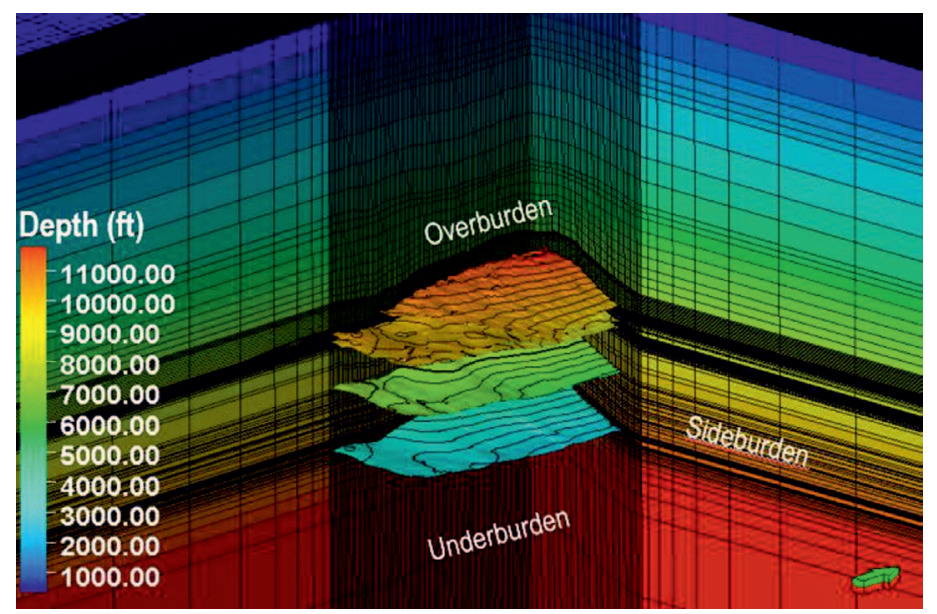

\section{D Reservoir Geomechanical Modelling}

Coupling between multi-phase fluid flow and rock deformations in the reservoir and surrounding formations is very important to better understand the behaviour of the field $[1,2,4]$. It is necessary to introduce the geomechanical effects through a stress analysis solution and to imple- ment a scheme that ensures that governing laws of the flow simulation and the stress analysis are obeyed simultaneously in each time step. To fully understand these interactions it was necessary to couple the geomechanical model with the fluid flow models, and ensure all relevant parameters 
were consistent between the two models. The importance of the pressure changes during the intervals between stress steps, is that they determine the amount of rock deformation, compaction and subsidence. In addition, the pore pressure change will induce a change in effective and total stresses, which in turn will have a direct impact on drilling conditions. This in turn leads to the recommended drilling mud weight changes at different production times. Figure 5 shows the pore pressure distribution at different production times. The purple zones represent the zones of high depletion. Changes in pore pressure due to injection/depletion induced significant changes in stresses (Figure 6). The greatest changes in minimum principal stress were located in regions with the highest depletion and injection.

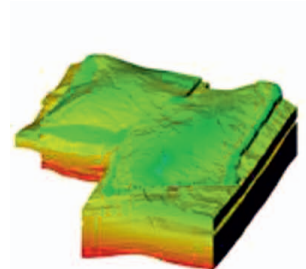

1968

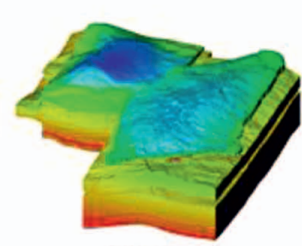

2000

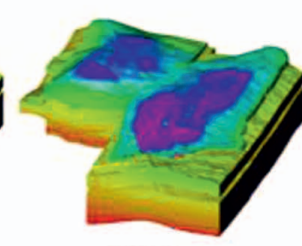

2013

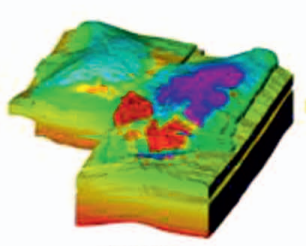

2017

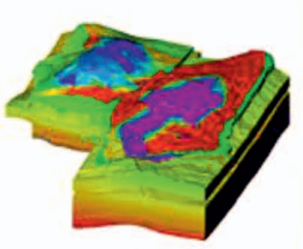

2025

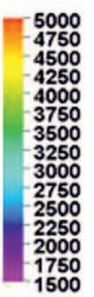

Fig. 5. Distribution of pore pressure (psi) at different production times

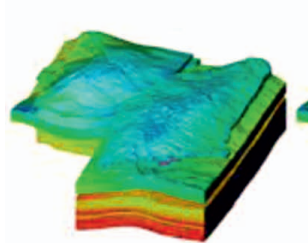

1968

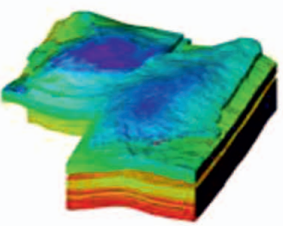

2000

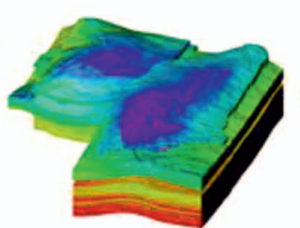

2013

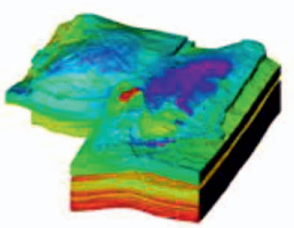

2017

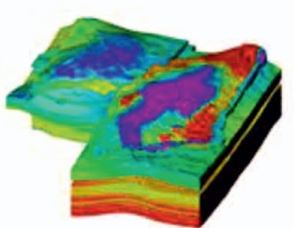

2025

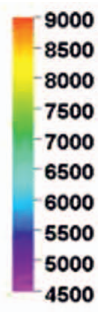

Fig. 6. Distribution of minimum principal stress (psi) at different production times

\section{D Mud Weight Cubes and Wellbore Stability Analysis}

Mud weight cubes are helpful for making decisions with regard to new well trajectories and well placements. They provide guidelines for the optimum wellbore directions for different formations and locations within the field.

Figure 7 shows the distribution of critical mud weights which induce breakout and mud losses mud weight in Ahmadi Shale, Wara Shale, Mauddud and Lower Burgan reservoir layers. This shows that Wara Shale has higher critical breakout
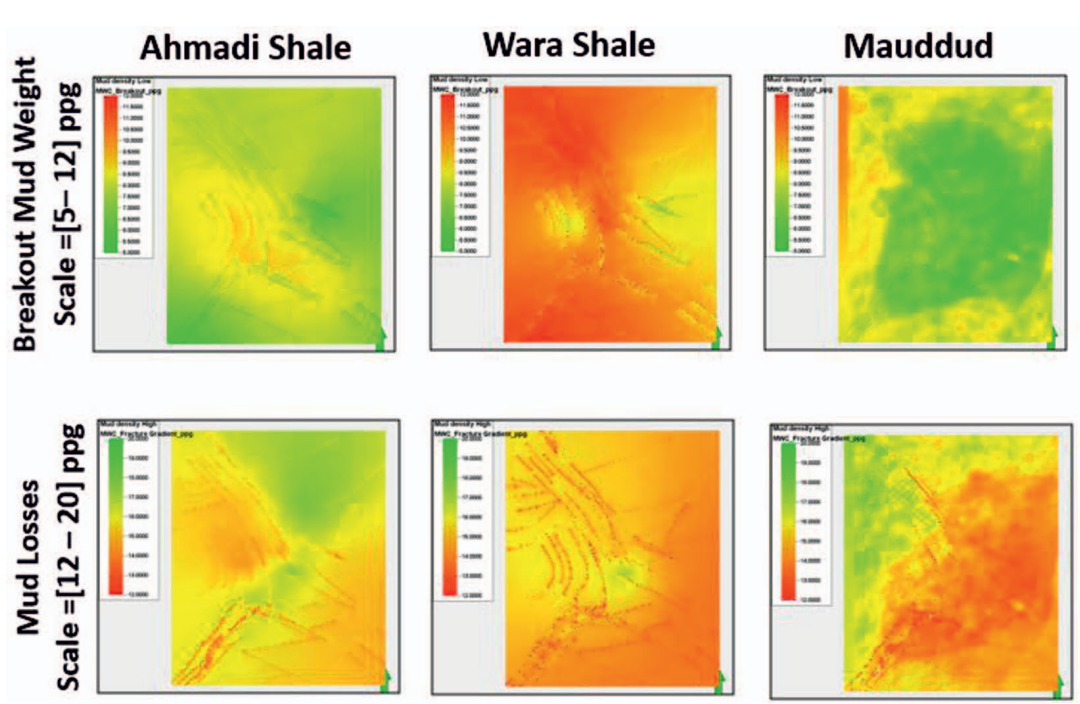

Fig. 7. Distribution of breakout and mud losses mud weight in key formations
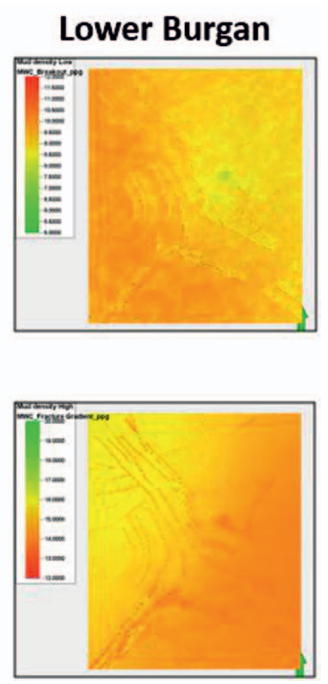

mud weight limit than other formations and therefore requires higher drilling mud weight. It is clear that mud losses are low within faults. The comparison between reservoir layers shows that drilling through the Lower Burgan requires higher mud weight than drilling through the Mauddud reservoir. Therefore, a detailed wellbore stability analysis is required for planned wells, and such analysis were conducted. Figure 8 illustrates an example of a key horizontal well. The analysis showed a narrow mud weight window within the Upper Burgan. Drilling the well with its planned trajectory posed significant risk to failure. It was thus suggested, to change the wellbore trajectory. An alternative well trajectory shows, that if the wellbore is shifted slightly to the west, then the stable mud weight window becomes wider. 


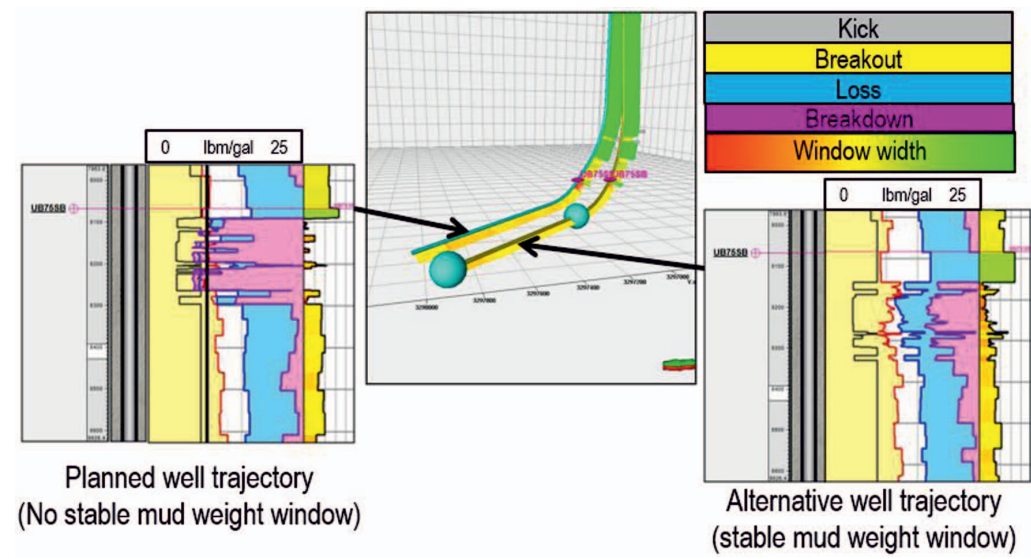

Fig. 8. Wellbore stability analysis for a planned well

\section{Conclusions}

A 4D geomechanical model was constructed for the Raudhatain and Sabriya fields in North Kuwait. The geomechanical model included the individual reservoirs. Coupled fluid-flowgeomechanical modelling was performed. The 3D stress state accounted in a consistent way for $3 \mathrm{D}$ variations in structure, mechanical properties and presence of faults. The results were used to generate 3D mud weight cubes. The width of the safe mud weight window was observed to vary for dif- ferent formations, and also to have lateral variations. Wara Shale has a higher breakout critical mud weight than other formations and therefore requires higher drilling mud weight. The results can be used to compute drilling mud weights that provide guidelines for the placement of new wells and necessary drilling mud weights along planned wells. Wellbore stability analysis was performed for a planned well in the Upper Burgan, and it helped to optimize the well trajectory.

Please cite as: Nafta-Gaz 2017, no. 3, pp. 157-161, DOI: 10.18668/NG.2017.03.02

Article contributed to the Editor 7.10.2016. Approved for publication 6.02.2017.

\section{Literature}

[1] Heffer K.J., Greenhough J., Main I., Zhang X., Mohamad Hussein A., Nasreldin G., Koutsabeloulis N.C.: Low-Cost Monitoring of Inter-well Reservoir Communication Paths through Correlations in Well Rate Fluctuations. Case Studies from Mature Fields in the North Sea. SPE EUROPEC/EAGE Annual Conference and Exhibition 2010.

[2] Koutsabeloulis N.C., Hope S.A.: Coupled Stress/Fluid/Thermal Multi-Phase Reservoir Simulation Studies Incorporating Rock Mechanics. SPE/ISRM 47393 Paper presented at the SPE Annual Technical Conference and Exhibition, Trondheim, Norway 1998, DOI: 10.2118/47393-MS.

\section{Safaa Mohamad DEIB}

Senior Geologist

Kuwait Oil Company (KOC)

RH6 0NZ

Ahmadi

Postal Code 61008, Kuwait

E-mail:SMarie@kockw.com

Hossam El-Din Ibrahim

Senior Geologist

Kuwait Oil Company (KOC)

P.O Box 9758

Ahmadi

Postal Code 61008, Kuwait

E-mail:HDIbrahim@kockw.com
[3] Milton D.I., Davies C.C.S.: Exploration and Development of the Raudhatain Field. Journal of the Institute of Petroleum 1965, vol. 51, no. 493, pp. 17-28.

[4] Mohamad Hussein A., Minton J., Rawnsley K., Qiuguo L., Zhang X., Koutsabeloulis K.: Coupled Reservoir Geomechanical Modeling of a Thermal Gas-Oil-Gravity-Drainage Project. SPE 127822 Paper presented at SPE EOR Conference at Oil \& Gas West Asia held in Muscat, Oman 2010, DOI: 10.2118/127822-MS.

\section{Assef MOHAMAD-HUSSEIN}

$\mathrm{PhD}$, Consultancy Technical Lead

Schlumberger Geomechanics Center of Excellence

Schlumberger House

First Floor

Gatwick Airport, West Sussex

EH6 0NZ, United Kingdom

E-mail:ahussein7@slb.com
Ali KHAN
Tpl Specialist I (geology)
Kuwait Oil Company (KOC)
P.O Box 9758
Ahmadi
Postal Code 61008, Kuwait
E-mail: ANKHAN@kockw.com 